\title{
Biocide plants as a sustainable tool for the control of pests and pathogens in vegetable cropping systems
}

\author{
Trifone D'Addabbo, ${ }^{1}$ Sebastiano Laquale, ${ }^{2}$ Stella Lovelli, ${ }^{2}$ Vincenzo Candido, ${ }^{2}$ \\ Pinarosa Avato $^{3}$ \\ 1'Institute for Sustainable Plant Protection, National Research Council, Bari; ${ }^{2}$ School of \\ Agricultural, Forest, Food and Environmental Sciences, University of Basilicata, Potenza; \\ ${ }^{3}$ Department of Pharmacy, University Aldo Moro of Bari, Italy
}

\begin{abstract}
Synthetic pesticides have played a major role in crop protection related to the intensification of agricultural systems. In the recent years, environmental side effects and health concerns raised by an indiscriminate use have led the EU to the ban of many synthetic pesticides. As a result of this drastic revision, currently there is a strong need for new and alternative pest control methods. An interesting source of biorational pesticides may be represented by the biocidal compounds naturally occurring in plants as products of the secondary metabolism. Groups of plant secondary metabolites most promising for the development of pesticidal formulations are glucosinolates, saponins, and more generally terpenoid phytoconstituents, such as essential oil and their constituents. Glucosinolates are thioglucosidic secondary metabolites occurring mainly in the Brassicaceae and, at a less extent, in Capparidaceae families. The incorporation of glucosinolate-containing plant material into the soil results in degradation products highly toxic to soilborne pest, pathogens and weeds. This practice, known as biofumigation, may be considered as an ecological alternative to soil toxic fumigants. Plant-derived saponins are triterpene glycosides present in top and root tissues of plant species of the families
\end{abstract}

Correspondence: Trifone D'Addabbo, Institute for Sustainable Plant Protection (IPSP), National Research Council, via G. Amendola 122/D, 70126 Bari, Italy.

Tel.: +39.971.205371 - Fax: +39.0971 .205378 .

E-mail: t.daddabbo@ba.ipp.cnr.it

Key words: phytoparasitic nematodes, sustainable control, plant secondary metabolites, vegetables.

Conference presentation: Meeting on Environmental Sustainability and Food Security, Potenza, Italy, 2014.

Received for publication: 24 July 2014.

Revision received: 6 October 2014.

Accepted for publication: 11 October 2014.

(C) Copyright T. D'Addabbo et al., 2014

Licensee PAGEPress, Italy

Italian Journal of Agronomy 2014; 9:616

doi:10.4081/ija.2014.616

This article is distributed under the terms of the Creative Commons Attribution Noncommercial License (by-nc 3.0) which permits any noncommercial use, distribution, and reproduction in any medium, provided the original author(s) and source are credited.
Leguminosae, Alliaceae, Asteraceae, Polygalaceae and Agavaceae. Saponins and saponin-rich plant materials have been also reported for a biocidal activity on phytoparasites and soilborne plant pathogens. Essential oils are volatile, natural, heterogeneous mixtures of single substances, mainly terpenes and phenolics, formed as secondary metabolites by aromatic plants belonging to several botanical families. Among terpenes, limonoid triterpenes have been demonstrated to possess interesting insecticidal, nematicidal and antifungal properties. Occurrence of these compounds is mainly limited to Meliaceae and Rutaceae. Alkaloids, phenolics, cyanogenic glucosides, polyacetylenes and polythienyls are further groups of secondary metabolites also known for their biocidal activity and susceptible for the production of natural pesticides. Alkaloids are derived from various botanical families, amongst which the Solacaneae, and include a number of molecules, such as nicotine, veratrine, cevatrine and ryanodine, used as insecticides. Phenolics were found also toxic to insects, fungi, bacteria, nematodes and weeds. Cyanogenic glucosides are amino acidderived secondary metabolites releasing, upon tissue disruption, hydrogen cyanide that suppress insects, fungus, nematodes and weeds. Finally, polyacetylenes and polythienyls, substances mainly present in Tagetes species, are also well known for their insecticidal and nematicidal properties.

\section{Introduction}

Plant-parasitic nematodes are among the most known crop pests, as worldwide distributed and responsible for substantial damages to horticultural crops of economic importance (Figure 1).

During the past decades, the control of these phytoparasites largely relied on treatments with chemical nematicides, mainly fumigants, most of which have been withdrawn after the drastic revision of synthetic pesticides operated at EC level (Directive 91/414, Regulation 2009/1107/EC and Directive 2009/128/EC; European Commission, 1991, 2009a, 2009b). Withdrawal of most available chemical nematicides and widespread public concern for long-term health and environmental effects of pesticides have generated a growing interest in alternative pest control tools (Ghorbani et al., 2008).

Plants are a huge source of nematicidal compounds, mainly constituents of the secondary metabolism involved in plant defence mechanisms against abiotic and biotic agents. These nematicidal compounds may be directly exploited as plant extracts, phytochemical formulations or organic amendments, or used as model compounds for the development of chemically synthesised derivatives. Plant-derived nematicides could fit well to the principles of Integrated Pest Management, thanks to their safety to environment, humans and animals, selective mode of action and absence of pest resistance (Chitwood, 2002). A further advantage of plant-based nematode management strategies is represented by their large flexibility, as the large 
variety of application modes allows adaptability to different crops, seasons and agricultural systems. In addition, they can easily combine with other control practices, such as soil solarisation, biocontrol agents and also synthetic nematicides. Finally, some techniques of exploitation of nematicidal plants, such as green manures or organic amendments may also result in an improvement of physical and chemical properties of the soil (Cherr et al., 2006).

A large number of plant species have been already reported to contain metabolites with nematicidal activity and new nematicidal plantderived compounds are discovered year by year (D'Addabbo et al., 2009; Ntalli and Caboni, 2012; Avato et al., 2013) (Figure 2).

Literature reports a large number of reviews on nematicidal plants, generally structured according to the chemical structure of active principles (Chitwood, 2002; D'Addabbo et al., 2009; Ntalli and Caboni, 2012; Avato et al., 2013). This paper will focus more specifically on the plant active compounds already resulted effective or with a high potential of application for nematode control in vegetable cropping systems of Southern Italy, almost correspondent to those of all the Mediterranean basin.

\section{Mechanisms of action and modes of use of nematicidal plants}

Nematode suppressiveness of phytochemicals can be the result of various and often-concomitant mechanisms, such as repellence, disorientation, nematode trapping, hatching stimulation or inhibition. Active principles present in plant tissues or released as root exudates may also have a direct toxicity to nematodes, causing mortality or only a temporary immobilization. Other plant metabolites may act as antifeedants, i.e. to cause a permanent or temporary interruption of nematode feeding. This is the case of absinthin, a dimeric sesquiterpene produced by Artemisia absinthium and responsible of an antifeedant activity on insects and nematodes. Some species, such as Raphanus sativus, can work as trapping plants, i.e. attracting the nematode inside the roots but blocking its reproduction and the completion of life cycle (Guesmi et al., 2013). Further suggested mechanisms have hypothesised an induction of morphological and physiological changes or a repellent activity on nematodes, such as for amines and pyridines (Feldmesser et al., 1976).

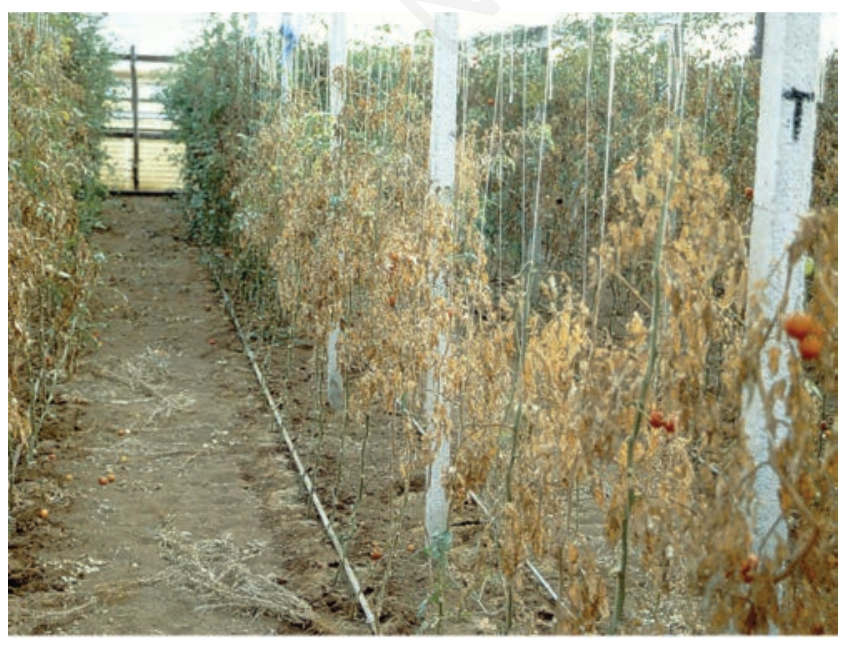

Figure 1. Damage to tomato crop in a greenhouse heavily infested by root-knot nematodes in Sicilia.
Modes of exploitation of the nematicidal properties of a plant species should be specifically adapted to the mechanisms of action. Agronomical practices, such as the incorporation into the soil of plant biomass, or rotation and intercropping with plants releasing nematotoxic allelochemicals in the soil, have been often demonstrated for an effective nematode suppression (Widmer and Abawi, 2000; D'Addabbo et al., 2009; Avato et al., 2013). Besides agronomical uses, an industrial production of commercial formulations based on extracts, oils, purified components or biomasses of nematicidal plants has also frequently occurred (Giannakou, 2011; D'Addabbo et al., 2011b; D'Addabbo et al., 2009; Ntalli et al., 2009; Colombo et al., 2012).

\section{Main chemical groups of nematicidal plant compounds}

\section{Glucosinolates}

Glucosinolates (GLSs) are thioglucosidic secondary metabolites, mainly present in the Brassicaceae and Capparidaceae families, which coexist in vivo with the myrosinase enzyme. Myrosinase-catalysed hydrolysis of glucosinolates, upon tissue damage by harvesting, processing or mastication, results in the release of a variety of isothiocyanate derivatives with nematotoxic action (Table 1).

Toxicity of Brassicaceae plant extracts, and of GLSs and related hydrolysis products, mainly isothiocyanates, has been widely investigated in several in vitro studies (Buskov et al., 2002; Oliveira et al., 2011; Wu et al., 2011). These studies are almost completely referred to root-knot nematodes, Meloidogyne species, or to the potato (Solanum tuberosum L.) cyst nematode Globodera rostochiensis Woll., though data were extended also to the GLSs' in vitro activity against the grapevine (Vitis vinifera L.) virus-vector nematode Xiphinema index Thorne et Allen and the carrot (Daucus carota L.) cyst nematode Heterodera carotae Jones (Figure 3) (Avato et al., 2013).

The volatility of most isothiocyanates and other GLS hydrolysis products led to coin the term biofumigation to describe the suppression of soil-borne pests and pathogens by biocidal volatiles released by brassicaceous rotation and green manure crops or by seed meal amendments incorporated into the soil (Angus et al., 1994; Smolinska et al., 1997; Matthiessen and Kirkegaard, 2006) (Figure 4). The negative impact of soil amendments with brassicaceous plant material on phytoparasitic

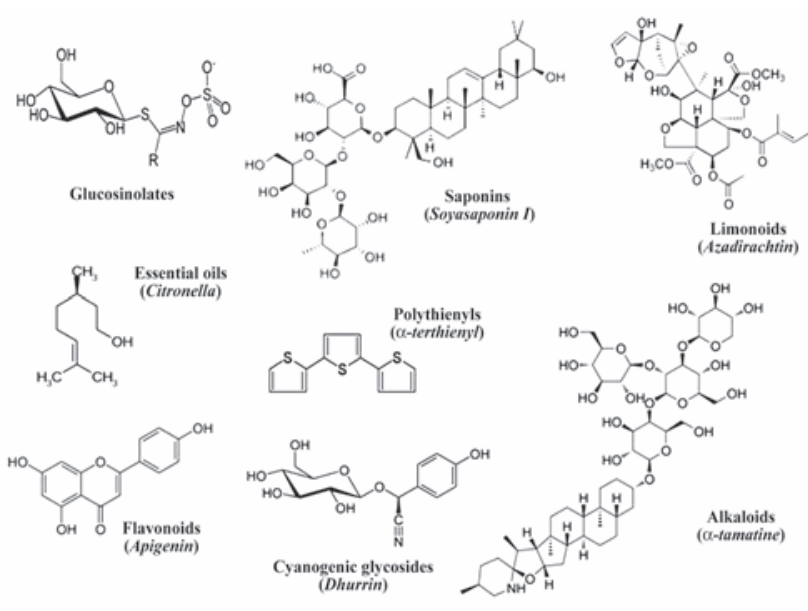

Figure 2. Examples of chemical structures from plants involved in the control of crop pests and soil pathogens. 
nematodes was documented since the early 90s (Mojtahedi et al., 1991, 1993b) and largely exploited during the following years (Potter et al., 1998; Zasada and Ferris, 2004; Monfort et al., 2007; Gimsing and Kirkegaard, 2009).

Content and chemical profile of glucosinolates and their degradation products depend on plant species/genotype, environment, phenological stage and tissue and, therefore, an appropriate management of these parameters is needed to select plant material with enhanced nematicidal potential to target organisms.

In addition to the species of genus Brassica spp., nematicidal potential of other Brassicaceae plants has been also investigated. Radish (Raphanus sativus L. ssp. oleiformis) or white mustard (Sinapis alba L. were satisfactorily applied as intercrop plants for the control of the sugarbeet cyst nematode Heterodera schachtii Schmidt, though the same species resulted differently suppressive on the root-knot nematode Meloidogyne incognita Kofoid et White (Chitw.) (Figure 5) (Guesmi et al., 2013). Rocket, Eruca sativa L., provided a remarkable biocidal effect against root-knot nematodes in field (Curto, 2008). Meadowfoam, Limnanthes alba Benth., is another promising GLS containing plant with a potential for the management of nematode pests (Zasada et al., 2012).

\section{Saponins}

Saponins are a large group of glycosidic secondary metabolites produced by many plant species, including major food crops, belonging to three major chemical classes: steroid glycosides; steroid alkaloid glycosides and triterpene glycosides, which include the largest number of structures.

Due to their chemical, physical and physiological characteristics, naturally occurring saponins display a broad spectrum of biological and pharmacological effects, also including fungicidal, molluscicidal, antibacterial and antiviral activities (Tava and Avato, 2006). Biological effects of saponins are normally ascribed to their specific interaction with the cell membranes, as causing changes in the cell permeability (Sprag et al., 2004; Tava and Avato, 2006).

Table 1. Percentage mortality of adult specimens of the virus vector nematode Xiphinema after 2,4 or $8 \mathrm{~h}$ of exposure to 0.05 , $0.30,1.0$ or $2.0 \mathrm{mg} \mathrm{mL}^{-1}$ solutions of different isothiocyanates.

\begin{tabular}{lcccc} 
Isothiocyanate & Rate & \multicolumn{3}{c}{ Mortality (\%) } \\
& $\left(\mathrm{mg} \mathrm{mL}^{-1}\right)$ & $2 \mathrm{~h}$ & $4 \mathrm{~h}$ & $8 \mathrm{~h}$ \\
Allil-isothiocyanate & 0.05 & $33.3^{\mathrm{b}}$ & $33.3^{\mathrm{b}}$ & $100^{\mathrm{c}}$ \\
& 0.30 & $33.3^{\mathrm{b}}$ & $40.0^{\mathrm{b}}$ & $100^{\mathrm{c}}$ \\
& 1.00 & $60^{\mathrm{c}}$ & $100^{\mathrm{d}}$ & $100^{\mathrm{c}}$ \\
& 2.00 & $100^{\mathrm{f}}$ & $100^{\mathrm{d}}$ & $100^{\mathrm{c}}$ \\
Feniletil-isothiocyanate & 0.05 & $16.7^{\mathrm{ab}}$ & $66.7^{\mathrm{cd}}$ & $100^{\mathrm{c}}$ \\
& 0.30 & $26.7^{\mathrm{b}}$ & $100^{\mathrm{d}}$ & $100^{\mathrm{c}}$ \\
& 1.00 & $56.7^{\mathrm{c}}$ & $100^{\mathrm{d}}$ & $100^{\mathrm{c}}$ \\
& 2.00 & $96.7^{\mathrm{ef}}$ & $10^{\mathrm{d}}$ & $100^{\mathrm{c}}$ \\
Benzil-isothiocyanate & 0.05 & $16.7^{\mathrm{ab}}$ & $40^{\mathrm{b}}$ & $73.3^{\mathrm{b}}$ \\
& 0.30 & $66.7^{\mathrm{cd}}$ & $63.3^{\mathrm{c}}$ & $96.7^{\mathrm{c}}$ \\
& 1.00 & $73.3^{\mathrm{cd}}$ & $100^{\mathrm{d}}$ & $100^{\mathrm{c}}$ \\
Butil-isothiocyanate & 2.00 & $76.7^{\mathrm{cde}}$ & $100^{\mathrm{d}}$ & $100^{\mathrm{c}}$ \\
& 0.05 & $33.3^{\mathrm{b}}$ & $93.3^{\mathrm{d}}$ & $83.3^{\mathrm{b}}$ \\
& 0.30 & $86.7^{\mathrm{def}}$ & $96.7^{\mathrm{d}}$ & $100^{\mathrm{c}}$ \\
& 1.00 & $100^{\mathrm{f}}$ & $100^{\mathrm{d}}$ & $100^{\mathrm{c}}$ \\
Water control & 2.00 & $100^{\mathrm{f}}$ & $100^{\mathrm{d}}$ & $100^{\mathrm{c}}$ \\
\hline
\end{tabular}

Modified from Avato et al., 2013. a-f Values with the same letters are not significantly different at $\mathrm{P}=0.05$ according to Fisher's least significant difference test.

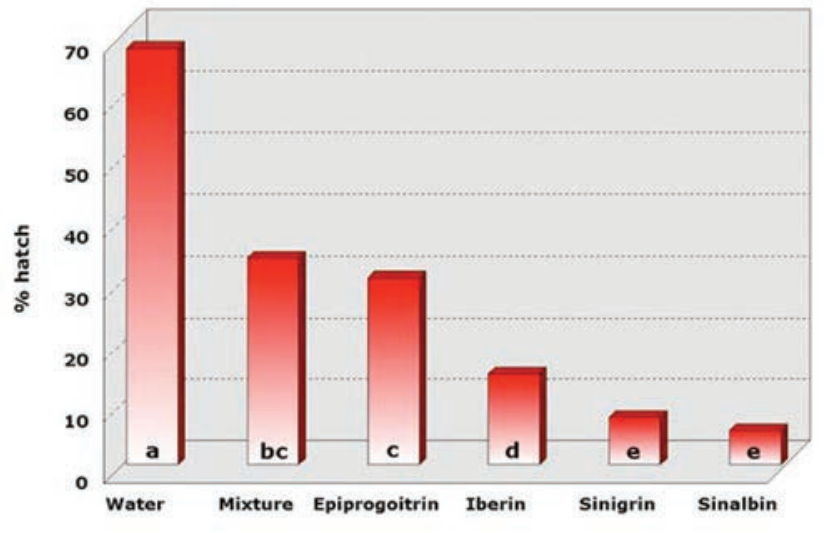

Figure 3. Effect of different glucosinolates on the hatching percentage of Heterodera carotae cysts.

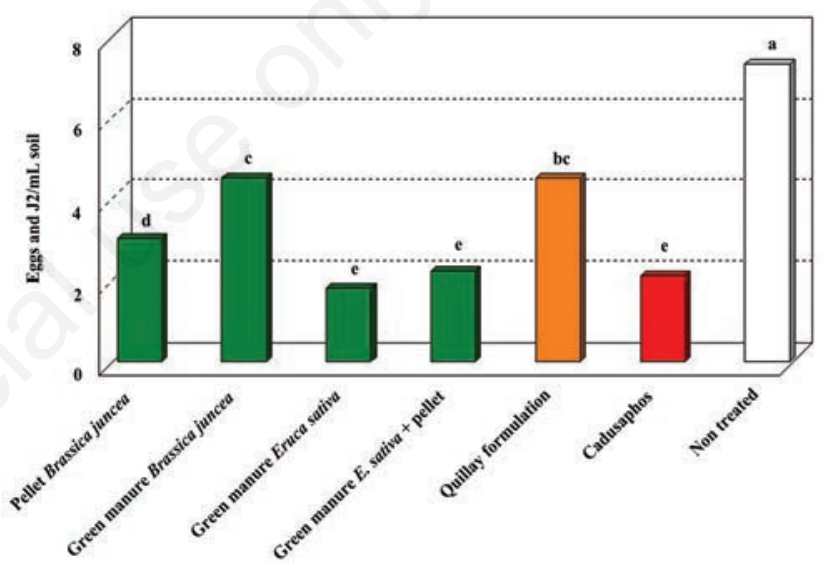

Figure 4. Effect of different biofumigation treatments on soil population of the root-knot nematode Meloidogyne incognita on tomato in greenhouse.

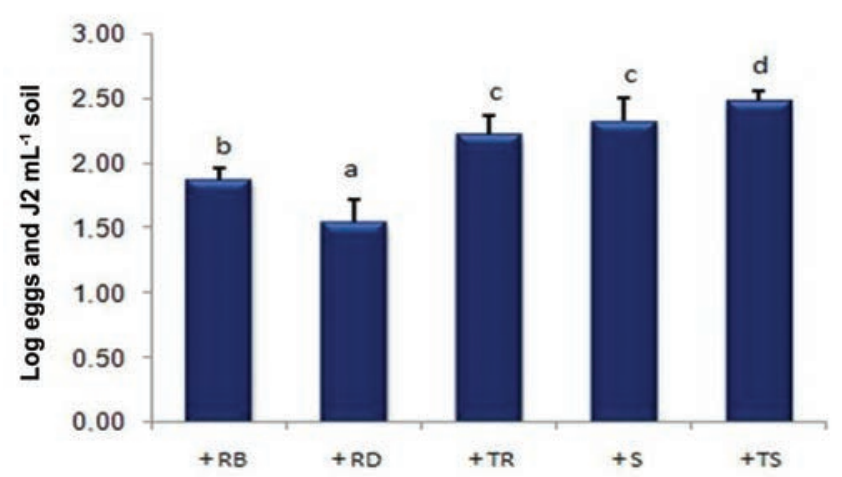

Figure 5. Effect of green manure with Raphanus sativus $\mathrm{cv}$. Boss (RB) and cv. Defender (RD) and with Sinapis alba (S+), in comparison with respective non treated controls ( $T R+$; $T S_{+}$), on soil population of the root-knot nematode Meloidogyne incognita on potted tomato. 
Literature on the nematicidal activity of saponins is quite limited. The in vitro and pot experiments of Omar et al. (1994) showed that 260-280 ppm solutions of saponins reduced total populations, number of egg masses and viable juveniles of the root-knot nematode Meloidogyne javanica Treub. Motility of $M$. incognita juveniles was reported as significantly reduced by the exposure to eight different steroid and triterpenoid saponins from Asparagus spp. (Chitwood, 2002). A formulation of saponins from the bark of quillay (Quillaja saponaria Molina) resulted in a satisfactorily nematode control also at low dosage (San Martin and Magnunacelaya, 2005). Moreover, field trials with aqueous extracts of $Q$. saponaria significantly reduced the density of $M$. incognita in the soil and increased tomato or melon crop yield (D’Addabbo et al., 2005) (Figure 6). Adversely, Argentieri et al. (2008) documented a poor nematicidal effect of an almost pure formulation of quillay saponins in an in vitro experiment on $X$. index. In the same experiment, pure saponins from different Medicago species were nematicidal on $X$. index, as inducing $100 \%$ mortality at $500 \mathrm{~g} \mathrm{~mL}^{-1}$ rate between 8 and 48 h exposures (Table 2).

Saponins found in the genus Medicago are triterpene glycosides and include different structural types, distinguished by their aglycones and

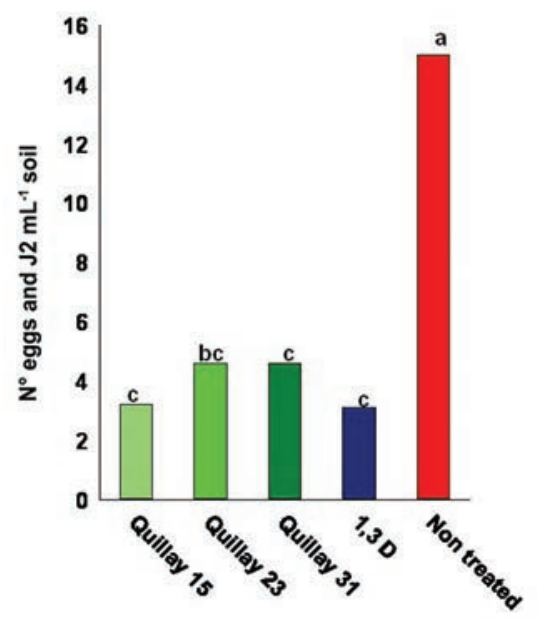

Figure 6. Effect of treatments with 15,23 and $30 \mathrm{~L} \mathrm{ha}^{-1}$ rates of quillay extract on final soil population of the root-knot nematode Medicago incognita on field tomato in Southern Italy.

Table 2. Effect of different concentrations of saponins from different Medicago species, Quillaja saponaria and Glycine max on Xiphinema index after different exposure times.

\begin{tabular}{|c|c|c|c|c|c|c|}
\hline \multirow[t]{2}{*}{ Rate ( $\left.\mathrm{gg} \mathrm{mL}^{-1}\right)$} & \multicolumn{6}{|c|}{ Nematode immobility (\%) } \\
\hline & $1 \mathrm{~h}$ & $2 \mathrm{~h}$ & $4 \mathrm{~h}$ & $8 \mathrm{~h}$ & $24 \mathrm{~h}$ & $48 \mathrm{~h}$ \\
\hline \multicolumn{7}{|c|}{ M. sativa tops } \\
\hline 0 & $0^{\mathrm{a}}$ & $0^{\mathrm{a}}$ & $0^{\mathrm{a}}$ & $0^{\mathrm{a}}$ & $0^{\mathrm{a}}$ & $0^{\mathrm{a}}$ \\
\hline 125 & $0^{\mathrm{a}}$ & $0^{\mathrm{a}}$ & $0^{\mathrm{a}}$ & $0^{\mathrm{a}}$ & $0^{a}$ & $0^{\mathrm{a}}$ \\
\hline 250 & $0^{\mathrm{a}}$ & $0^{\mathrm{a}}$ & $0^{\mathrm{a}}$ & $0^{\mathrm{a}}$ & $0^{\mathrm{a}}$ & $0^{\mathrm{a}}$ \\
\hline 500 & $0^{a}$ & $38.1^{\mathrm{e}}$ & $61.9^{\mathrm{e}}$ & $100^{e}$ & $100^{g}$ & $100^{g}$ \\
\hline \multicolumn{7}{|c|}{ M. sativa roots } \\
\hline 0 & $0^{\mathrm{a}}$ & $0^{\mathrm{a}}$ & $0^{\mathrm{a}}$ & $0^{\mathrm{a}}$ & $0^{\mathrm{a}}$ & $0^{\mathrm{a}}$ \\
\hline 125 & $0^{\mathrm{a}}$ & $0^{\mathrm{a}}$ & $0^{\mathrm{a}}$ & $0^{a}$ & $9.5^{\mathrm{abc}}$ & $33.3^{\text {cd }}$ \\
\hline 250 & $0^{\mathrm{a}}$ & $0^{\mathrm{a}}$ & $0^{\mathrm{a}}$ & $0^{\mathrm{a}}$ & $47.6^{\mathrm{e}}$ & $61.9^{\mathrm{ef}}$ \\
\hline 500 & $0^{\mathrm{a}}$ & $4.8^{\mathrm{ab}}$ & $33.3^{\mathrm{cd}}$ & $66.7^{\mathrm{d}}$ & $100^{g}$ & $100^{9}$ \\
\hline \multicolumn{7}{|c|}{ M. arabica tops } \\
\hline 0 & $0^{\mathrm{a}}$ & $0^{\mathrm{a}}$ & $0^{\mathrm{a}}$ & $0^{\mathrm{a}}$ & $0^{\mathrm{a}}$ & $0^{\mathrm{a}}$ \\
\hline 125 & $0^{\mathrm{a}}$ & $0^{a}$ & $0^{a}$ & $0^{\mathrm{a}}$ & $19.0^{c}$ & $38.1^{\mathrm{d}}$ \\
\hline 250 & $0^{\mathrm{a}}$ & $0^{\mathrm{a}}$ & $0^{\mathrm{a}}$ & $0^{\mathrm{a}}$ & $42.8^{\mathrm{de}}$ & $76.2^{\mathrm{f}}$ \\
\hline 500 & $0^{\mathrm{a}}$ & $9.5^{\mathrm{ab}}$ & $23.8^{\mathrm{bc}}$ & $90.5^{\mathrm{e}}$ & $100^{g}$ & $100^{g}$ \\
\hline \multicolumn{7}{|c|}{ M. arabica roots } \\
\hline 0 & $0^{\mathrm{a}}$ & $0^{\mathrm{a}}$ & $0^{\mathrm{a}}$ & $0^{\mathrm{a}}$ & $0^{\mathrm{a}}$ & $0^{\mathrm{a}}$ \\
\hline 125 & $0^{a}$ & $0^{a}$ & $0^{a}$ & $0^{\mathrm{a}}$ & $57.1^{\mathrm{e}}$ & $71.4^{\mathrm{f}}$ \\
\hline 250 & $0^{\mathrm{a}}$ & $0^{\mathrm{a}}$ & $0^{\mathrm{a}}$ & $0^{\mathrm{a}}$ & $47.6^{\mathrm{e}}$ & $90.5^{\mathrm{tg}}$ \\
\hline 500 & $0^{\mathrm{a}}$ & $0^{\mathrm{a}}$ & $0^{\mathrm{a}}$ & $0^{\mathrm{a}}$ & $80.9^{f}$ & $100^{g}$ \\
\hline \multicolumn{7}{|c|}{ M. arborea tops } \\
\hline 0 & $0^{\mathrm{a}}$ & $0^{\mathrm{a}}$ & $0^{\mathrm{a}}$ & $0^{\mathrm{a}}$ & $0^{\mathrm{a}}$ & $0^{\mathrm{a}}$ \\
\hline 125 & $0^{\mathrm{a}}$ & $0^{\mathrm{a}}$ & $0^{\mathrm{a}}$ & $0^{a}$ & $4.8^{\mathrm{ab}}$ & $14.3^{\mathrm{abc}}$ \\
\hline 250 & $0^{\mathrm{a}}$ & $0^{\mathrm{a}}$ & $0^{\mathrm{a}}$ & $0^{a}$ & $4.8^{\mathrm{ab}}$ & $4.8^{\mathrm{ab}}$ \\
\hline 500 & $0^{\mathrm{a}}$ & $0^{a}$ & $4.8^{\mathrm{ab}}$ & $61.9^{\mathrm{d}}$ & $100^{g}$ & $100^{g}$ \\
\hline \multicolumn{7}{|c|}{ Q. saponaria bark } \\
\hline 0 & $0^{\mathrm{a}}$ & $0^{\mathrm{a}}$ & $0^{\mathrm{a}}$ & $0^{\mathrm{a}}$ & $0^{\mathrm{a}}$ & $0^{\mathrm{a}}$ \\
\hline 125 & $0^{\mathrm{a}}$ & $9.5^{\mathrm{bc}}$ & $9.5^{\mathrm{abc}}$ & $4.8^{\mathrm{ab}}$ & $14.3^{\mathrm{bc}}$ & $14.3^{\mathrm{abc}}$ \\
\hline 250 & $0^{\mathrm{a}}$ & $14.3^{\mathrm{cd}}$ & $14.3^{\mathrm{bc}}$ & $14.3^{\mathrm{c}}$ & $19.0^{c}$ & $23.8^{\mathrm{cd}}$ \\
\hline 500 & $0^{\mathrm{a}}$ & $9.5^{\mathrm{ab}}$ & $14.3^{\mathrm{abc}}$ & $14.3^{b c}$ & $19.0^{c}$ & $19.0^{\mathrm{bcd}}$ \\
\hline \multicolumn{7}{|c|}{ Soyasaponin I } \\
\hline 0 & $0^{\mathrm{a}}$ & $0^{\mathrm{a}}$ & $0^{\mathrm{a}}$ & $0^{\mathrm{a}}$ & $0^{\mathrm{a}}$ & $0^{\mathrm{a}}$ \\
\hline 125 & $0^{\mathrm{a}}$ & $0^{\mathrm{a}}$ & $4.8^{\mathrm{ab}}$ & $9.5^{\mathrm{bc}}$ & $9.5^{\mathrm{abc}}$ & $14.3^{\mathrm{abc}}$ \\
\hline 250 & $0^{\mathrm{a}}$ & $0^{\mathrm{a}}$ & $4.8^{\mathrm{ab}}$ & $4.8^{\mathrm{ab}}$ & $28.6^{\mathrm{cd}}$ & $42.8^{\mathrm{de}}$ \\
\hline 500 & $0^{\mathrm{a}}$ & $0^{\mathrm{a}}$ & $0^{\mathrm{a}}$ & $0^{\mathrm{a}}$ & $14.3^{\mathrm{bc}}$ & $42.8^{\mathrm{de}}$ \\
\hline
\end{tabular}

a-g Values with the same letters are not significantly different at $\mathrm{P}=0.05$ according to Fisher's least significant difference test. 
sugars, which have some chemotaxonomic relevance to discriminate among the various species within the genus (Tava and Avato, 2006; Tava et al., 2009).

Although the exact function of saponins in Medicago plants is not fully understood, they are regarded as constitutive resistance factors involved in defence mechanisms especially against pathogens.

Saponins from Medicago sativa L., as showing a well characterised chemical composition and well established biological activities, seem to represent good candidates for phytonematode control. The in vitro investigation of the biocidal effects of saponin mixtures from alfalfa top and root tissues on $X$. index, $M$. incognita and $G$. rostochiensis showed that saponins from both plant parts were nematotoxic to the three phytoparasite species and their activity was dependent on the concentration and nematode incubation time (Argentieri et al., 2008; D'Addabbo et al., 2011a).

Bioactivity data from these in vitro experiments suggested exploring also the efficacy of Medicago plant material to suppress plant parasitic nematode populations through soil amendments (D'Addabbo et al., 2009). Soil amendments with leaf and root dry biomass of $M$. sativa were found to reduce root and soil population densities of $M$. incognita and $G$. rostochiensis compared to a non-treated control, according to a doserelated relationship (Figure 7). Further field experiments evidenced the high suppressiveness of a pelleted formulation of $M$. sativa dry biomass on $M$. incognita on tomato and on the cyst nematode $H$. carotae on carrot (D’Addabbo et al., 2010) (Table 3). However, results suggest that phytonematode suppression in amended soil could be only partially attributed to the saponin content of $M$. sativa tissues, as the presence of active
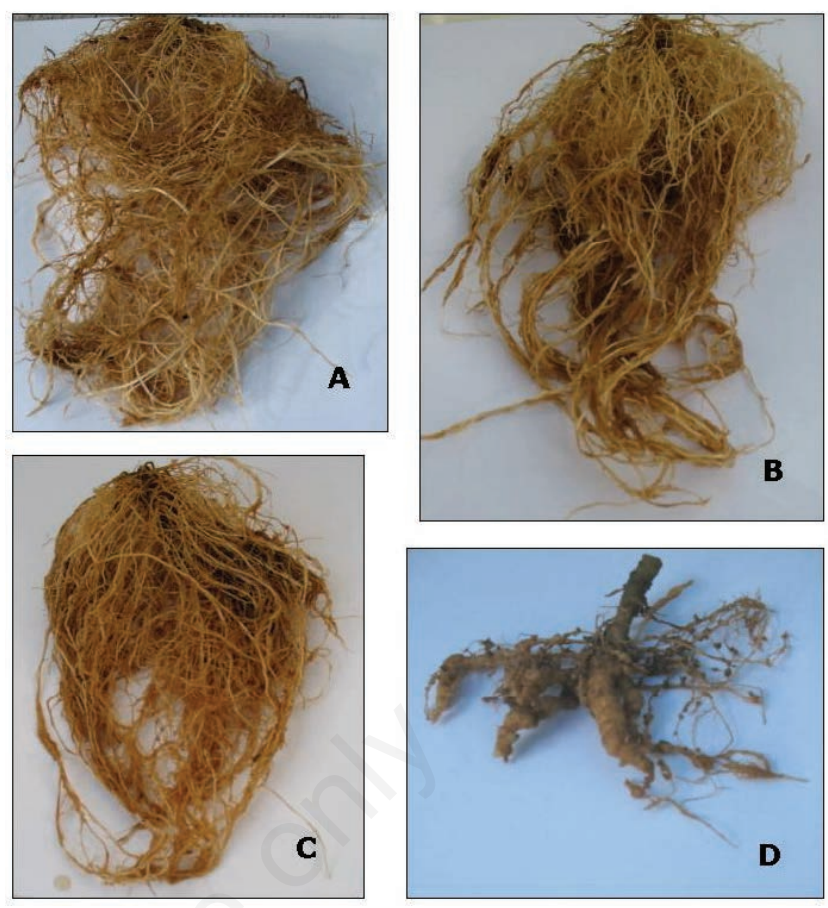

Figure 7. Tomato roots from soil uninfested (A), treated with $2 \%$ Medicago sativa dry leaves (B), treated with fenamiphos (C) and untreated (D).

Table 3. Effect of soil amendments with alfalfa pellets on yield tomato and soil population density of the root-knot nematode Meloidogyne incognita on carrot and of the cyst nematode Heterodera carotae on carrot.

\begin{tabular}{|c|c|c|c|c|c|}
\hline \multirow[t]{2}{*}{ Treatment } & \multirow[t]{2}{*}{ Rate } & \multicolumn{2}{|c|}{ Crop yield $\left(\mathrm{T} \mathrm{ha}^{-1}\right)$} & \multicolumn{2}{|c|}{$\begin{array}{l}\text { Nematode population } \\
\text { (eggs and J2 } \mathrm{mL}^{-1} \text { soil) }\end{array}$} \\
\hline & & Tomato & Carrot & Tomato & Carrot \\
\hline Alfalfa pellet & 20 t ha $^{-1}$ & $68.6^{c}$ & $75.6^{\mathrm{b}}$ & $3.2^{\mathrm{c}}$ & $11.6^{\mathrm{bc}}$ \\
\hline Alfalfa pellet & 40 t ha $^{-1}$ & $71.6^{\mathrm{c}}$ & $76.0^{\mathrm{bc}}$ & $1.5^{\mathrm{d}}$ & $7.5^{\mathrm{c}}$ \\
\hline Quillay extract & $30 \mathrm{~L} \mathrm{ha}^{-1}$ & $55.5^{\mathrm{b}}$ & $59.6^{\mathrm{a}}$ & $3.8^{\mathrm{bc}}$ & $22.3^{\mathrm{ab}}$ \\
\hline Fenamiphos & $30 \mathrm{~L} \mathrm{ha}^{-1}$ & $58.3^{\mathrm{b}}$ & $107.2^{\mathrm{d}}$ & $2.7^{\mathrm{cd}}$ & $8.6^{\mathrm{c}}$ \\
\hline Control & - & $46.0^{\mathrm{a}}$ & $58.2^{\mathrm{a}}$ & $5.2^{\mathrm{a}}$ & $32.0^{\mathrm{a}}$ \\
\hline
\end{tabular}

a-d Values with the same letters are not significantly different at $\mathrm{P}=0.05$ according to Fisher's least significant difference test.

Table 4. Effect of treatments with quillay and azadirachtin formulations on carrot yield and soil population density of Heterodera carotae in Sicilia.

\begin{tabular}{|c|c|c|c|c|}
\hline Treatment & $\begin{array}{c}\text { Dose } \\
(\mathrm{L} \mathrm{ha-1})\end{array}$ & Time of application & $\begin{array}{l}\text { Crop yield } \\
\left(\mathrm{T} \mathrm{ha}^{-1}\right)\end{array}$ & $\begin{array}{l}\text { Nematode population } \\
\text { (eggs and } \mathrm{J} 2 \mathrm{~g}^{-1} \text { soil) }\end{array}$ \\
\hline Quillay & 20 & Before sowing & $38^{b}$ & $15^{b}$ \\
\hline Quillay & 30 & Before sowing & $34^{\mathrm{ab}}$ & $16^{\mathrm{b}}$ \\
\hline Quillay & 40 & Before sowing & $35^{\mathrm{ab}}$ & $20^{b}$ \\
\hline Azadirachtin (2.5\%) & $3+3$ & Before sowing + emergence & $31^{\mathrm{ab}}$ & $18^{b}$ \\
\hline Azadirachtin (1.0\%) & $7+7$ & Before sowing + emergence & $26^{\mathrm{a}}$ & $32^{c}$ \\
\hline Azadirachtin (1.0\%) & 4 & Before sowing & $20^{\mathrm{a}}$ & $34^{c}$ \\
\hline Phosthiazate & $4^{*}$ & Before sowing & $144^{c}$ & $10^{\mathrm{a}}$ \\
\hline Non treated soil & - & Before sowing & $20^{\mathrm{a}}$ & $38^{c}$ \\
\hline
\end{tabular}

a,b,cValues with the same letters are not significantly different at $\mathrm{P}=0.05$ according to Fisher's least significant difference test. ${ }^{*} \mathrm{~kg}$ ha $^{-1}$. 
metabolites other than saponins, such as phenolics and canavanine, or the release of nematotoxic ammoniacal nitrogen should be also considered (Natelson, 1985; Bailey and Lazarovits, 2003).

\section{Limonoid triterpenes}

Limonoids are a group of metabolically altered triterpenes occurring in species belonging to Rutaceae and mainly Meliaceae families, though limonoids from the neem tree (Azadirachta indica A. Juss.) are the most widely investigated for their biological activities (Akhtar, 2000). Neem contains more than 100 limonoid compounds, including azadirachtin, salannin, and nimbin, mainly working as repellents, feeding deterrents and insect growth inhibitors (Schmutterer, 1990). Azadirachtin is the most known neem limonoid, due to its activity against insects and phytoparasitic nematodes (Akhtar, 2000; Oka et al., 2007) (Table 4). Soil treatments with azadiractin formulations, either alone or combined with other nonchemical techniques, such as soil solarisation, demonstrated to be effective mainly for reducing root-knot nematode infestation and increasing crop yield in several field and greenhouse experiments in Central and Southern Italy (Caroppo et al., 2005; Colombo et al., 2005). However, the nematicidal effect of neem formulations was also demonstrated on cyst-nematode species, such as Heterodera cajani Koshy and Heterodera glycines Ichinoe (Mojumder and Raman, 1999; Rodrigues et al., 2001).

\section{Essential oils}

Essential oils (EOs) are secondary metabolites produced by aromatic plant species from many botanical families, such as Myrtaceae, Lauraceae, Lamiaceae, Asteraceae. E0s are mixtures of volatile compounds, including low molecular weight terpenes and phenolics constituents, that play a major role in plant chemical defence against insects, fungal pathogens and also nematodes (Bakkali et al., 2008). Chemical composition, toxicity and bioactivity of EOs are largely affected by climate and agronomical and technical factors, as the plant phenological stage and the method of extraction (Lahlou, 2004). Due to a low mammalian toxicity and persistence in the environment, as well as to a low induction of resistance in target organisms, EOs are more and more considered as good candidates for the development of new sustainable nematicidal formulations.

As exhaustively reviewed by Andrés et al. (2012), a large number of EOs from different botanical families has been analysed in vitro for their nematicidal activity, mainly against root-knot nematodes and the pinewood nematode Bursaphelenchus xylophilus Nickle. In particular, a high toxicity to root-knot nematodes has been reported for the EOs from Cymbopogon spp., Mentha spp., Eucalyptus spp., Pelargonium graveolens L'Hér. and Ocimun basilicum L. (Sangwan et al., 1990; Leela

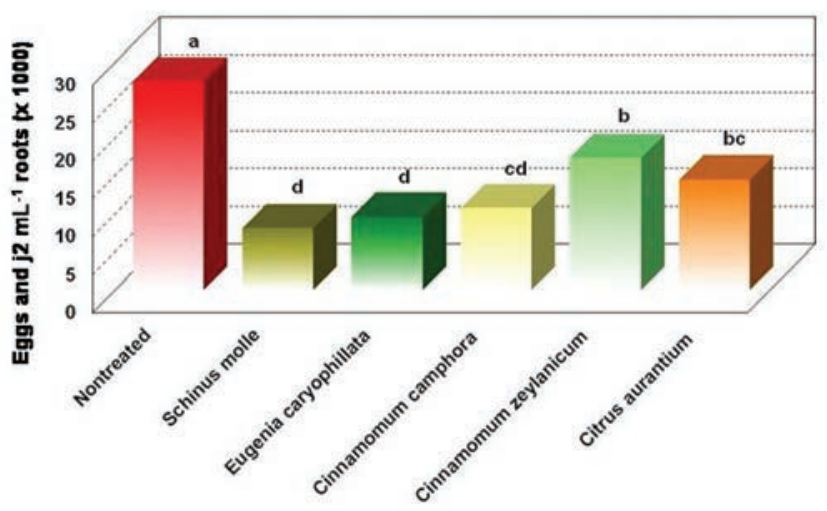

Figure 8. Aggregate effects of tretments with essential oils of Schinus molle, Cinnamomum camphora, Eugenia caryophillata, Cinnamomum zeylanicum and Citrus aurantium on the pulation of the root-knot nematode Meloidogyne incognita on potted tomato.

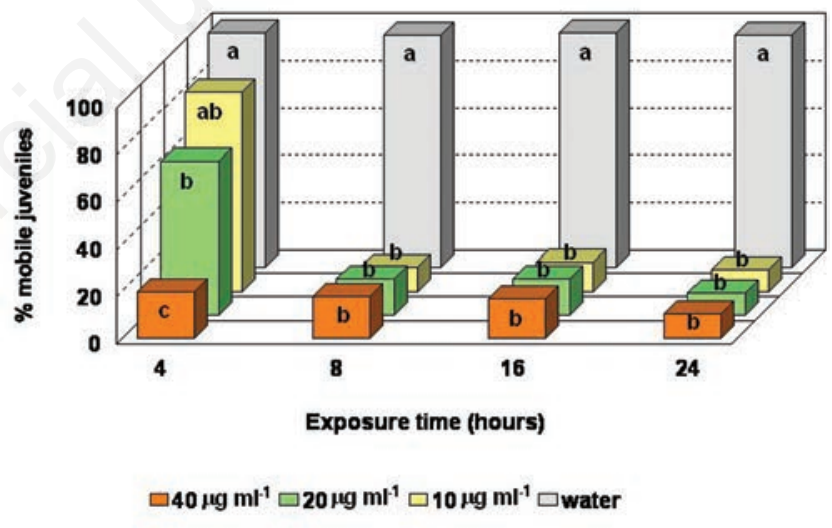

Figure 9. Effect of the exposure to different concentrations of Tagetes erecta extract on immobility/mortality of the juveniles of the root-knot nematode Meloidogyne incognita.

Table 5. Effect of treatments with formulates of Quillaja saponaria and Tagetes erecta on field tomato yield and infestation of the rootknot nematode Meloidogyne incognita in Southern Italy.

\begin{tabular}{|c|c|c|c|c|}
\hline Formulate & $\begin{array}{l}\text { Rate }\left(\mathrm{L} \mathrm{ha}^{-1}\right) \\
\text { and timing }\end{array}$ & Yield $\left(\mathrm{T} \mathrm{ha}^{-1}\right)$ & $\begin{array}{l}\text { Root gall index } \\
\qquad(0-5)\end{array}$ & $\begin{array}{l}\text { Final nematode population } \\
\text { (eggs and } \mathrm{J} 2 \mathrm{~mL}^{-1} \text { soil) }\end{array}$ \\
\hline Q. saponaria & 30 at transplant & $55.5^{\mathrm{bc}}$ & $3.1^{\mathrm{b}}$ & $3.8^{\mathrm{bc}}$ \\
\hline Q. saponaria & $20+10$ at transplant and $15 \mathrm{dd}$ after transplant & $58.7^{\text {cde }}$ & $1.9^{c}$ & $1.7^{\mathrm{d}}$ \\
\hline Q. saponaria & $10+10+10$ at transplant and 15 and 30 dd after transplant & $60.2^{\mathrm{de}}$ & $1.8^{c}$ & $1.8^{\mathrm{d}}$ \\
\hline T. erecta & 40 at transplant & $61.9^{\mathrm{e}}$ & $3.7^{\mathrm{ab}}$ & $4.7^{\mathrm{ab}}$ \\
\hline T. erecta & $30+10$ at transplant and $15 \mathrm{dd}$ after transplant & 59.9 de & $3.3^{b}$ & $3.5^{\mathrm{c}}$ \\
\hline T. erecta & $20+10+10$ at transplant and 15 and $30 \mathrm{dd}$ after transplant & $53.7^{\mathrm{b}}$ & $3.4^{\mathrm{ab}}$ & $3.8^{\mathrm{bc}}$ \\
\hline Fenamiphos & 367 dd before transplant & $58.3^{\text {cd }}$ & $1.8^{c}$ & $2.3^{\mathrm{d}}$ \\
\hline Non treated & - & $46.0^{\mathrm{a}}$ & $4.0^{\mathrm{a}}$ & $5.2^{\mathrm{a}}$ \\
\hline
\end{tabular}

${ }^{a-e}$ Values with the same letters are not significantly different at $\mathrm{P}=0.05$ according to Fisher's least significant difference test. 
et al., 1992; Oka et al., 2000; Pandey et al., 2000; Batish et al., 2008; Ntalli et al., 2010). Toxicity of a large number of EOs to B. xylophilus has been reported mainly by studies from Korea and Portugal, as these countries are severely affected by the presence of this nematode (Kong et al., 2006; Barbosa et al., 2010).

Much fewer data are available on the in vivo effect of EOs on phytonematodes. A consistent suppression of $M$. incognita population on tomato roots after soil drench treatments with water emulsions of EOs from Schinus molle L., Cinnamomum camphora (L.) J. Presl, Eugenia caryophillata Thunb., Cinnamomum zeylanicum Blume and Citrus aurantium L. has been recently reported by Laquale et al. (2013b) (Figure 8). The same authors also documented the nematicidal effect of soil treatments with EOs of Eucalyptus citriodora Hook. and Eucalyptus globulus Labill. on the same nematode species (Laquale et al., 2013a).

\section{Polythienyls}

Polythienyls are substances with insecticidal and nematicidal properties, present in species of the Asteraceae family and mainly in the genus Tagetes (Chitwood, 2002). The most known polythienyls are surely those responsible for the nematicidal activity of Tagetes erecta $\mathrm{L}$. (Uhlenbroek and Bijloo, 1958) (Figure 9). The nematicidal effect of Tagetes species, used either as a source of nematode-antagonistic formulations or as cover, green manure or rotation crops, has been reported by a large number of studies (Wang et al., 2007; Hooks et al., 2010). In field and greenhouse experiments, a commercial formulation of the aqueous extract of $T$. erecta effectively controlled the infestation of $M$. incognita on tomato (Solanum lycopersicum L.) both in Southern and Northern Italy, resulting also in a stimulating effect on crop growth and yield (Curto et al., 2006; D’Addabbo et al., 2008) (Table 5).

\section{Alkaloids}

Alkaloids are nitrogen-containing natural secondary metabolites from several botanical families, amongst which also the Solanaceae, though the highest activity against phytonematodes was reported for pyrrolizidine alkaloids from Fabaceae species, but also from Liliaceae, Apocynaceae and Papaveraceae (Thoden et al., 2009). A nematicidal activity has been documented also for steroidal alkaloids, such as $\alpha$ tomatine and $\alpha$-chaconine and solanine (Chitwood, 2002).

\section{Phenolics, flavonoids and tannins}

Phenolics are known as toxic to insects, fungi, bacteria, weeds and also nematodes (Ohri and Pannu, 2010). Among phenolics, a consistent nematicidal activity was often reported for flavonoids (Ntalli and Caboni, 2012), a large group of secondary metabolites with a key role in plant defence against insects, fungal and bacterial pathogens and viral diseases.

A role in plant protection from predators and parasites is also played by tannins, polyphenolic compounds widely present in many plant species and documented for their activity on phytoparasitic nematodes (Hewlett et al., 1999). Soil treatments with tannic acid were found to effectively control the infestation of the root-knot nematode Meloidogyne arenaria Chitw. on squash (Cucurbita pepo L.) (Mian and Rodriguez-Kabana, 1982). Application to the soil of a commercial formulation of the tannins from chestnut (Castanea sativa Mill.) significantly reduced the population of $M$. javanica on potted tomato (Maistrello et al., 2010).

\section{Cyanogenic glycosides}

Cyanogenic glucosides are cyanide-releasing aminoacid-derived glycosides, involved in the defense of more than 2500 plant species against predators and parasites. Cyanide is one of the decomposition products of the $\beta$-glucosidase-hydrolysis of glycoside molecule, occurring upon plant tissue disruption by predators or by mechanical incorporation of plant materials into the soil. Green manure of sudangrass, Sorghum sudanense (Piper) Stapf. Poaceae, is widely reported for its suppressiveness on root-knot nematodes (Mojtahedi et al., 1993a; Widmer and Abawi, 2000) due to the soil fumigating effect of the cyanide released by the hydrolisis of dhurrin, a cyanogenic glucoside largely present in sudangrass.

\section{Conclusions}

This short review confirms once more that nematicidal plants and their phytochemicals can play a relevant role in the sustainable management of phytoparasitic nematodes, either in organic and conventional vegetable cropping systems. In organic systems, nematicidal plant-based techniques can represent a fundamental nematode management tool, due to the poor availability of admitted control methods. In conventional agriculture, plant-derived nematicidal formulations can be applied as stand-alone treatments in short-cycle crops, in which risk of residues in the final products does not allow treatments with synthetic nematicides. Combination of plant formulations with synthetic nematicides is recommended for long-cycle crops and, more generally, in the presence of high initial nematode densities. Use of nematicidal plant-based agronomical techniques, such as green manures, rotations or intercropping, is more suitable to extensive crop systems, whereas liquid, meal and pelleted industrial formulations should be the first choice in the intensive systems, where the strict crop successions do not allow the application of agronomical methods.

Finally, a careful cost-benefit evaluation is needed before the application of any nematode control strategies based on biocidal plants, as plant commercial formulations are expensive and agronomical techniques are cheaper but time and labour consuming.

\section{References}

Akhtar M, 2000. Nematicidal potential of the neem tree Azadirachta indica (A. Juss). Integrated Pest. Manag. Rev. 5:57-66.

Andrés MF, González-Coloma A, Sanz J, Burillo J, Sainz P, 2012. Nematicidal activity of essential oils: a review. Phytochem. Rev. 11:371-90.

Angus JF, Gardner PA, Kirkegaard JA, Desmarchelier JM, 1994. Biofumigation: isothiocyanates released from Brassica roots inhibit growth of the take-all fungus. Plant Soil. 162:107-12.

Argentieri MP, D’Addabbo T, Tava A, Agostinelli A, Jurzysta M, Avato P, 2008. Evaluation of nematicidal properties of saponins from Medicago spp. Eur. J. Plant Pathol. 120:189-97.

Avato P, D’Addabbo T, Leonetti P, Argentieri MP, 2013. Nematicidal potential of Brassicaceae. Phytochem. Rev. 12:791-802.

Bailey KL, Lazarovits G, 2003. Suppressing soil-borne diseases with residue management and organic amendments. Soil. Till. Res. $72: 169-80$.

Bakkali F, Averbeck S, Averbeck D, Idaomar M, 2008. Biological effects of essential oils - a review. Food Chem. Toxicol. 46:446-75.

Barbosa P, Lima AS, Vieira P, Dias LS, Tinoco MT, Barroso JG, 2010. Nematicidal activity of EOs and volatiles derived from portuguese aromatic flora against the pinewood nematode, Bursaphelenchus xylophilus. J. Nematol. 42:8-16.

Batish DR, Singh HP, Kohli RK, Kaur S, 2008. Eucalyptus essential oil as a natural pesticide. Forest Ecol. Manag. 256:2166-74. 
Buskov S, Serra B, Rosa E, Sørensen H, Sørensen JC, 2002. Effects of intact glucosinolates and products produced from glucosinolates in myrosinase-catalyzed hydrolysis on the potato cyst nematode (Globodera rostochiensis Woll). J. Agr. Food Chem. 50:690-5.

Caroppo S, Coniglio D, Capella A, Ambrogioni L, 2005. Azione di due diversi formulati di azadiractina nei confronti di Meloidogyne incognita su pomodoro in ambiente controllato. Inf. Fitopatol. $55: 38-42$.

Chitwood DJ, 2002. Phytochemical based strategies for nematode control. Ann. Rev. Phytopathol. 40:221-49.

Cherr CM, Scholberg JMS, McSorley R, 2006. Green manure approaches to crop production. Agron. J. 98:302-19.

Colombo A, Cataldi S, Marano G, Genna G, 2012. Control of the rootknot nematode, Meloidogyne incognita, in organic protected crops in Sicily. Redia. 94:127-31.

Colombo A, Cataldi S, Serges T, Barraco D, 2005. Management of the southern root-knot nematode, Meloidogyne incognita, on tomato in Sicily using azadirachtin (Neem). Nematol. Medit. 33:19.

Curto G, 2008. Sustainable methods for management of cyst nematodes. In: A. Ciancio, K.G. Mukerji (eds), Integrated management and biocontrol of vegetable and grain crops nematodes. Springer, Berlin, Germany, pp 221-237.

Curto G, Dallavalle E, Lazzeri L, Santi R, 2006. Verifica di strategie alternative per il contenimento di Meloidogyne incognita nel pomodoro da mensa in coltura protetta. Atti Giorn. Fitopatol. 2006:225-32

D’Addabbo T, Avato P, Tava A, 2009. Nematicidal potential of materials from Medicago spp. Eur. J. Plant Pathol. 125:39-49.

D’Addabbo T, Carbonara T, Leonetti P, Radicci V, Tava A, Avato P, 2011a. Control of plant parasitic nematodes with active saponins and biomass from Medicago sativa. Phytochem. Rev. 10:503-19.

D'Addabbo T, Curto G, Greco P, Di Silvestro D, Coiro MI, Lamberti F, Ferrari V, Santi R, Carella A, 2005. Prove preliminari di lotta contro nematodi galligeni mediante estratti di Quillaja saponaria Molina. Nematol. Medit. 33:29-34.

D’Addabbo T, Greco P, Radicci V, 2008. Efficacia di formulati commerciali di origine vegetale nella lotta contro i nematodi galligeni. Atti Giorn. Fitopatol. 1:317-22.

D’Addabbo T, Radicci V, Avato P, Tava A, 2010. Use of pelleted Medicago sativa meal for the control of root-knot and cyst nematodes. Acta Hort. 883:303-8.

D’Addabbo T, Radicci V, Lucarelli G, Carella A, Bemad D, Martin E, 2011b. Effectiveness of a formulation from Pedaliaceae plants (Nematon ${ }^{\circledR}$ EC) for the control of the root-knot nematode Meloidogyne incognita on greenhouse tomato. Acta Hort. 914:233-6.

European Commission, 1991. Council Directive 91/414/EEC of 15 July 1991 concerning the placing of plant protection products on the market. In: Official Journal L 230, 19/8/1991, pp 1-32.

European Commission, 2009a. Directive 2009/128/EC of the European Parliament and of the Council of 21 October 2009 establishing a framework for Community action to achieve the sustainable use of pesticides. In: Official Journal L 309, 24/11/2009, pp 71-86.

European Commission, 2009b. Regulation (EC) No. 1107/2009 of the European Parliament and of the Council of 21 October 2009 concerning the placing of plant protection products on the market and repealing Council Directives 79/117/EEC and 91/414/EEC. In: Official Journal L 309, 24/11/2009, pp 1-50.

Feldmesser J, Thompson MJ, Robbins WE, Sponaugle RP, 1976. Nematicidal activity of secondary and tertiary alkyl amides and amines. Experientia. 32:466-7.

Giannakou I0, 2011. Efficacy of a formulated product containing Quillaja saponaria plant extracts for the control of root-knot nema- todes. Eur. J. Plant Pathol. 130:587-96.

Gimsing AL, Kirkegaard JA, 2009. Glucosinolates and biofumigation: fate of glucosinolates and their hydrolysis products in soil. Phytochem Rev. 8:299-310.

Ghorbani R, Wilcockson S, Koochek A, Leifert C, 2008. Soil management for sustainable crop disease control: a review. Environ. Chem Lett. 6:149-62.

Guesmi I, D’Addabbo T, Radicci V, Horrigue-Raouani N, 2013. Evaluation of the suppressive effects of three Brassica green manures on Meloidogyne incognita. Page 67 (Abstract) in Proc. ISOFAR - MOAN Symposium "Crop protection management in Mediterranean organic agriculture", 14-16 May 2013, Sousse, Tunisia.

Hewlett TE, Hewlett EM, Dickson DW, 1999. Response of Meloidogyne spp., Heterodera glycines and Radopholus similis to tannic acid. J. Nematol. 29:737-41.

Hooks CR, Wang KH, Ploeg A, McSorley R, 2010. Using marigold (Tagetes spp.) as a cover crop to protect crops from plant-parasitic nematodes. Appl. Soil Ecol. 46:307-20.

Kong J, Lee S, MoonY, Lee S, Ahn Y, 2006. Nematicidal activity of plant EOs against Bursaphelenchus xylophilus (Nematoda: Aphelenchoididae). J. Asia Pac. Entomol. 9:173-8.

Lahlou M, 2004. Methods to study the phytochemistry and bioactivity of essential oils. Phytother Res. 18:435-48.

Laquale S, Sasanelli N, D’Addabbo T, 2013a. Attività biocida di olii essenziali di specie di Eucalyptus nei confronti del nematode galligeno Meloidogyne incognita. Page 55 (Abstract) in Atti del I Congr. Naz. Società Italiana per la Ricerca sugli Oli Essenziali (S.I.R.0.E.), 15-17 novembre 2013, Roma, Italy.

Laquale S, Sasanelli N, D’Addabbo T, 2013b. Suppressiveness of selected essential oils on the root-knot nematode Meloidogyne incognita in soil. Page 64 (Abstract) in Proc. 44th Int. Symp. on Essential Oils (ISE0 2013), 8-12 September 2013, Budapest, Hungary.

Leela NK, Khan RM., Reddy PP, Nidiry ESJ, 1992. Nematicidal activity of essential oil of Pelargonium graveolens against the root-knot nematode Meloidogyne incognita. Nematol Medit. 20:57-8.

Maistrello L, Vaccari G, Sasanelli N, 2010. Effect of chestnut tannins on the root-knot nematode Meloidogyne javanica. Helminthologia 47:48-57.

Matthiessen JN, Kirkegaard JA, 2006. Biofumigation and enhanced biodegradation: opportunity and challenge in soilborne pest and disease management. Crit. Rev. Plant Sci. 25:235-65.

Mian IH, Rodriguez-Kabana R, 1982. Organic amendments with high tannin and phenolic contents for control of Meloidogyne arenaria in infested soil. Nematropica 12:221-34.

Mojtahedi H, Santo GS, Hang AN, Wilson JH, 1991. Suppression of rootknot nematodes with selected rapeseed cultivars as green manures. J. Nematol. 23:170-4.

Mojtahedi H, Santo GS, Ingham RE, 1993a. Suppression of Meloidogyne chitwoodi with sudangrass cultivars as green manure. J. Nematol. 25:303.

Mojtahedi H, Santo GS, Wilson JH, Hang AN, 1993b. Managing Meloydogine chitwoodi on potato with rapeseed as green manure. Plant Dis. 74:42-6.

Mojumder V, Raman R, 1999. Nematicidal efficacy of Neema-SI, an experimental formulation for neem seed treatment against Heterodera cajani and Meloidogyne incognita in cowpea and chickpea, respectively. In: Singh R.P and Saxena R.C. (Eds.), Azadiracta indica A. Juss. Science Publ. Inc., Enfield, NH, USA, pp 217-222.

Monfort WS, Csinos AS, Desaeger J, Seebold K, Webster TM, Diaz-Perez JC, 2007. Evaluating Brassica species as an alternative control measure for root-knot nematode (M. incognita) in Georgia vegetable plasticulture. Crop. Prot. 26:1359-68. 
Natelson S, 1985. Canavanine in alfalfa (Medicago sativa). Experientia 41:257-9.

Ntalli NG, Caboni P, 2012. Botanical nematicides: a review. J. Agric. Food Chem. 60:9929-40.

Ntalli NG, Ferrari F, Giannakou I, Menkissoglu-Spiroudi U, 2010. Phytochemistry and nematicidal activity of the essential oils from 8 Greek Lamiaceae aromatic plants and 13 terpene components. J. Agric. Food Chem. 58:7856-63.

Ntalli NG, Menkissoglu-Spiroudi U, Giannakou IO, ProphetouAthanasiadou DA, 2009. Efficacy evaluation of a neem (Azadirachta indica A. Juss) formulation against root-knot nematodes Meloidogyne incognita. Crop. Prot. 28:489-94.

Ohri P, Pannu SK, 2010. Effect of phenolic compounds on nematodes-A review. J. Appl. Nat. Sci. 2:344-50.

Oka Y, Nacar S, Putievsky E, Ravid U, Yaniv Z, Spiegel Y, 2000. Nematicidal activity of essential oils and their components against the root-knot nematode. Phytopathology 90:710-5.

Oka Y, Tkachi N, Shuker S, Yerumiyahu U, 2007. Enhanced nematicidal activity of organic and inorganic ammonia-releasing amendments by Azadirachta indica extracts. J. Nematol. 39:9.

Oliveira RDL, Dhingra OD, Lima A0, Jham GN, Berhow MA, Holloway RK, Vaughn SF, 2011. Glucosinolate content and nematicidal activity of Brazilian wild mustard tissues against Meloidogyne incognita in tomato. Plant Soil. 341:155-64.

Omar SA, Abdel-Massih MI, Mohamed BE, 1994. Use of saponins to control the root-knot nematode Meloidogyne javanica in tomato plants. Bull. Faculty Agric. Cairo (Egypt) 45:933-40.

Pandey R, Kalra A, Tandon S, Mehrotra N, Singh HN, Kumar S, 2000. EOs as potent sources of nematicidal compounds. J. Phytopathol. 148:501-2.

Potter MJ, Davies K, Rathjen AJ, 1998. Suppressive impact of glucosinolates in Brassica vegetative tissues on root lesion nematode Pratylenchus neglectus. J. Chem. Ecol. 24:67-80.

Rodrigues AC, Jham GN, Oliveira RD, 2001. Mortality of the soybean cyst nematode in aqueous extracts of neem plant parts. Nematol. Medit. 29:173-5.

San Martin R, Magunacelaya JC, 2005. Control of plantparasitic nema- todes with extracts of Quillaja saponaria. Nematology 7:577-85.

Sangwan NK, Verma BS, Verma KK, Dhindsa KS, 1990. Nematicidal activity of some essential plant oils. Pestic. Sci. 28:331-5.

Schmutterer H, 1990. Properties and potential of natural pesticides from the neem tree, Azadirachta indica. Ann. Rev. Entomol. 35:271-97.

Smolinska U, Morra MJ, Knudsen GR, Brown PD, 1997. Toxicity of glucosinolate degradation products from Brassica napus seed meal towards Aphanomyces euteiches f. sp. pisi. Phytopathology 87:77-82.

Sprag SG, Light ME, van Staden J, 2004. Biological activities and distribution of plant saponins. J Ethnopharm. 94:219-43.

Tava A, Avato P, 2006. Chemical and biological activity of triterpene saponins from Medicago species. NPC. 1:1159-80.

Tava A, Mella M, Avato P, Biazzi E, Pecetti L, Bialy Z, Jurzysta M, 2009. New triterpenic saponins from the aerial parts of Medicago arabica (L.) Huds. J. Agric. Food Chem. 57:2826-35.

Thoden TC, Boppré M, Hallmann J, 2009. Effects of pyrrolizidine alkaloids on the performance of plant-parasitic and free-living nematodes. Pest Manag. Sci. 65:823-30.

Uhlenbroek JH, Bijloo JD, 1958. Investigations on nematicides. I. Isolation and structure of a nematicidal principle occurring in Tagetes roots. Recl. Trav. Chim. Pay B 77:1004-9.

Zasada IA, Ferris H, 2004. Nematode suppression with brassicaceous amendments: application based upon glucosinolate profiles. Soil Biol. Biochem. 36:1017-24.

Zasada IA, Weiland JE, Reed RL, Stevens JF, 2012. Activity of meadowfoam (Limnanthes alba) deed meal glucolimnanthin degradation products against soilborne pathogens. J. Agric. Food Chem. 60:339-45.

Wang KH, Hooks C, Ploeg A, 2007. Protecting crops from nematode pests: using marigold as an alternative to chemical nematicides. Cooperative Extension Service, CTAHR, PD-35. Available from: http://www.ctahr.hawaii.edu/oc/freepubs/pdf/PD-35.pdf

Widmer TL, Abawi GS, 2000. Mechanism of suppression of Meloidogyne hapla and its damage by a green manure of Sudan grass. Plant Dis. 84:562-8.

Wu H, Wang C-J, Bian X-W, Zeng S-Y, Lin K-C, Wu B, Zhang G-A, Zhang $X, 2011$. Nematicidal efficacy of isothiocynates against root-knot nematode Meloidogyne javanica on cucumber. Crop. Prot. 30:33-7. 